\title{
Assessing the Need for Ecotourism Cluster Establishment in Georgia: Ways \\ to Increase the Country's Competitiveness
}

ESJ Social Sciences

\section{Tamar Khakhishvili}

School of Business Administration, Grigol Robakidze University, Georgia

Submitted: 11 June 2020

Accepted: 23 November 2020

Published: 30 November 2020

Corresponding author:

Mariam Sulashvili

DOI: 10.19044/esj.2020.v16n31p1

(c) Copyright 2020 Tamar Khakhishvili Distributed under Creative Commons BY-NC-ND 4.0 OPEN ACCESS

\begin{abstract}
Georgia is famous for wine, hospitality, culture, and history at the international level. Before now, tourism in Georgia was only related to wine tourism and sea resorts, but in recent years, the country is positioning itself as an emerging destination for adventurous tourism. Industry potential is not fully utilized and it has more hidden possibilities to attract more visitors. This paper focuses on assessing the need for ecotourism cluster establishment in Georgia. In fulfilling this objective, a survey was conducted. Questionnaires were distributed to ecotourism service providers of the country. 54 managers of national parks and other protected areas (Lagodekhi Protected Areas, Kazbegi National Park, Martvili Canyon Natural Monument, Borjomi-Kharagauli National Park and Machakhela National Park) were chosen for the survey. The selected respondents are the managers of the most popular ecotourism destinations among Georgian and foreign ecoturists. Due to the various locations in different parts of Georgia, it took about two weeks to conduct the survey. The results of the survey showed that ecotourism industry representatives agree on the need of cluster establishment for more development of the field. The paper also demonstrated that building promising ecotourism industry through strong cluster development is directly related to increasing the country's competitiveness.
\end{abstract}

Subject: Business, Ecotourism

Keywords: Ecotourism, business, cluster, competitiveness 


\section{Introduction}

Building competitiveness is an objective of every business and emerging nation (Porter, 2008). Every organization strives to find its key strengths. Organizations try to foster their abilities and transform them into competitive advantage. Thereafter, the organizations can begin to position rightly and gradually increase their coverage of the market.

The same can be said for countries as well. Firstly, countries intend to identify their strengths, enforce them, and only afterwards win over competitors (Porter, 2008). However, what is the strength of the country? Is it so easy to figure out? Many countries make mistakes in naming their major strengths. Therefore, this leads to incorrect country priorities and inaccurate development strategies.

Tourism in Georgia has always been recognized as promising and there have always been signs of future success in this field (Gavasheli, 2018). It is derived from reality that the country is famous for being hospitable and provides visitors with friendly environment, wonderful wine, and delicious cuisine. On the other hand, Georgia is an emerging ecotourism destination with amazing landscapes, wetlands and rainforests ${ }^{1}$ (Europarc Federation, 2019), high-mountain waterfalls, and semi-arid regions that can be visited within few hours drive (Gogelia, 2013).

According to Hector Ceballos-Lascurain (2008), Ecotourism is not only visitation to relatively undisturbed natural areas, but it also supports local population. Martha Honey (1991) also described ecotourism as the tool for educating travelers, which directly benefits economic development and empowerment of local communities. The thought that ecotourism encourages socio-economic involvement of local people and improves their living conditions is also expressed by International Union for Conservation of Nature (1996). IUCN ensures that tourism generates the full range of benefits for locals. Thus, ecotourism has become very important for potentially reconciling conservation and economic considerations (Drumm, 2005).

On the other hand, this paper underlines one of the most important ideas related to the country's competitiveness theory known as "Clusters". Clusters represent a prominent feature on the landscape of every economy, especially for developed countries (Porter, 2008). Michael Porter stresses that cluster formation is an essential ingredient of economic development. There is an idea that once a cluster is formed, the whole group of industries become mutually supporting (Porter, 2008).

\section{Objectives}

${ }^{1}$ Colchic Rainforests and wetlands - located in Georgia, along the warm-temperate and extremely humid eastern coast of the Black Sea. Colchic Rainforests and wetlands are nominated for inscription on the UNESCO World Heritage list (Europarc Federation, 2019). 
Since clusters occupy an important position in the strategies of developed countries, this paper focuses on assessing the country's potential to create cluster in one of the most developing field known as ecotourism. This paper also highlights the perspectives of developing Georgian ecotourism cluster through consideration of theoretical framework and collecting opinions of relevant representatives of the field.

\section{Methods}

After analyzing the data and scientific papers about ecotourism and clusters in Georgia, it was decided that conducting a survey would be the most relevant method for the study. The study was carried out in 5 most popular Protected Areas Administrations ${ }^{2}$ in Georgia (Lagodekhi, Kazbegi, Martvili, Borjomi-Kharagauli, and Machakhela). Questionnaires were distributed to 54 representatives of the administrations, including directors of the administrations, heads of Park Protection Divisions, as well as Administrative Divisions, Rangers, and Visitor Service Specialists. These administrations were selected for the study due to the fact that they host the majority of ecotourists in the country. Also, most of the ecotourism businesses are located in the surroundings of these areas. Since the administrations cooperate with them, they have a lot of information about their needs and potentials for development.

The questionnaire contained 12 items. The questions were selected with the specific principle. This was done so that the answers could give essential information to assess the readiness and willingness of ecotourism businesses, local population, and visitors to create ecotourism cluster in Georgia.

\section{Theoretical Framework Why Clusters Matters}

The fact that businesses are slowly developing in Georgia poses a new problem. According to different researches, there are several reasons for it such as lack of finances, unfriendly business environment, competition, no funds for start-ups, etc (Sepashvili, 2014). In this situation, like many other countries, the lack of cooperation between businesses still remains a challenge (Porter, 2008). Since many international organizations work hard to encourage clusters' development in Georgia, the concept is still new in the country. The development of the concept started late in Georgia. This fact is explained by the negative impact of the soviet era and hardship period of 1990s in the scientific field (Gagnidze, 2012). At the same time, clusters represent tools for

\footnotetext{
${ }^{2}$ Protected Areas are managed by Administrations which are governmental structures under the Agency of Protected Areas, Ministry of Environmental Protection and Agriculture of Georgia.
} 
competition exacerbation and building cooperation (Porter, 2008). Once competition and cooperation within the industry can coexist, cluster can enhance the competitiveness. Porter (2008) calls clusters a "driving force" which aid in increasing exports and magnets foreign investments. In his book on competition, Porter (2008, p. 215) states that: "They [clusters] constitute a forum in which new types of dialogue can, and must, take place among firms, government agencies, and institutions (such as schools, universities and public utilities)."

In the article "How Economic Clusters Drive Globalization", Julia Hanna (2017) talks about clusters and stresses that they have wider impact on world economics than generally recognized. She mentions the words of Harvard Fellow, Valeria Giacomin, who refers to clusters as "the building blocks of the global economy." In the working paper "A Historical Approach to Clustering in Emerging Economies", Giacomin (2017) notes that clusters have been around long before they had a name, showing up in the development of colonial-era industries and even earlier. However, Giacomin believes that clusters became platforms for development, which have present-day implications for corporations, governments, and individual actors, especially in emerging economies.

Quite often, companies are beginning to ask questions about clusters. This is because they are not always sure whether joining clusters is a good idea or not. Therefore, why should companies start clustering? European experience shows that cooperation and synergy between companies can make $1+1=3$. European Cluster Panorama Factsheet 2016 provides information about the benefits of European clusters. It reveals updated perspectives on clusters and emerging industries. This is drawn on a new firm-level data set on entrepreneurship and re-industrialization (Ketels \& Protsiv, 2017). Cluster Panorama Factsheet shows how important clusters are for economic activities throughout Europe. The mapping tool identifies 3000 strong clusters ranking in the top $20 \%$ of regions in their respective field of related industries. The data is really impressive. It shows that, through these clusters, more than 54 million jobs are created and $45 \%$ of all traded industries' wages are incorporated within (23\% of the overall economy). The figures also prove that fast growing new businesses (i.e., gazelles) account for $40 \%$ of the cluster. The Panorama Factsheet also stressed that organizations which are within the clusters pay higher wages than the same industries elsewhere. Also, they have stayed resilient throughout the crisis, slightly increasing their share of economic activity between 2008 and 2014.

The information of European Cluster Panorama Factsheet 2016 is also presented in the paper "The power of business clusters" by Paul Hackett (2019). Hackett underlines the importance of cooperation within the clusters and stressed that huddling together can derive benefits such as cutting supply 
chain costs or hiring qualified specialists easily. It can also lead to increased innovation, collaboration, and productivity.

\section{Ecotourism in Georgia}

Clusters have proven to be effective tools for cooperation, and building cooperation makes even more sense once it occurs in high potential sectors (Giacomin, 2017). In Georgia, the advantages and existing strengths have continuously been explored within the years. There is no doubt that wine and tourism industries are considered as growth industries and they experience higher-than-average growth rates compared to other sectors (Baratashvili, Kurashvili \& Makharashvili, 2018). Nowadays, Georgia needs to find more promising fields that could be a flagship industry for economic development.

Tourism has been recognized as the sector that shows the light at the end of the tunnel. After all the problems encountered during the Post-Soviet period, Georgia started increasing awareness internationally as an emerging tourism destination (Sekhniashvili, 2016). Rapid growth was recorded after 2010 especially as the impact of 2008 world financial crisis was conquered. According to the statistical data (Georgian National Tourism Administration, 2020), Georgia hosted more than 9 million international visitors in 2019. Taking into consideration that the population of the country is just 3.7 Million (National Statistics Office of Georgia, 2020), the number of visitors is quite impressive.

Table 1. Number of International Visitors of Georgia, 2008-2019

\begin{tabular}{llllllllllll}
\hline $\mathbf{2 0 0 8}$ & $\mathbf{2 0 0 9}$ & $\mathbf{2 0 1 0}$ & $\mathbf{2 0 1 1}$ & $\mathbf{2 0 1 2}$ & $\mathbf{2 0 1 3}$ & $\mathbf{2 0 1 4}$ & $\mathbf{2 0 1 5}$ & $\mathbf{2 0 1 6}$ & $\mathbf{2 0 1 7}$ & $\mathbf{2 0 1 8}$ & $\mathbf{2 0 1 9}$ \\
\hline 1,290, & 1,500, & 2,031, & 3,115, & 4,741, & 5,734, & 5,888, & 6,305, & 6,719, & 7,902, & 8,679, & $9,357,964$ \\
108 & 049 & 717 & 527 & 346 & 898 & 709 & 635 & 975 & 509 & 544 & \\
\hline \multicolumn{8}{c}{ Source: Georgian National Tourism Administration }
\end{tabular}

Source: Georgian National Tourism Administration

If wine has been the main reason for visiting Georgia, recreational tourism has become more popular for travelers in the recent years (Sekhniashvili, 2016). However, Georgia's recreational potential is not yet fully developed (Chigogidze, 2016). The area of Georgia is $69,700 \mathrm{~km}^{2}$ (National Statistics Office of Georgia, 2020). In spite of the small area, the country is famous for unique and diverse ecosystems such as forests, wetlands, lakes, rivers, waterfalls, glaciers, canyons, and deserts (Ministry of Environment and Natural Resources Protection of Georgia, 2014). The uniqueness of the forests is also derived from the location. Colchic Rainforests, located in West Georgia, have survived from the tertiary period and are characterized with relict species (Ministry of Environmental Protection and Agriculture of Georgia, 2019). Thus, the country has a lot to share to the rest of the world. 
It is worthy to note that the ecotourism potential of the country is collected within protected areas of the country. Protected areas of Georgia cover more than $9.5 \%$ of the whole country incorporating strict nature reserves, national parks, managed reserves, natural monuments, and protected landscape (Agency of Protected Areas, n.d.). All these areas create wonderful opportunities for visitors. The prospects of protected areas are widely discussed by Merab Diasamidze in his research (2015). He stresses that businesses working in the sector should unite their efforts to address the challenge if they strive to reach their greatest potential.

Furthermore, protected areas of Georgia are the most visited ecotourism destinations in the country. Ecotourism at protected areas is developing and hosting more than one million visitors per year (Agency of Protected Areas, n.d.).

Table 2. Number of visitors of protected areas of Georgia, 2012-2019

\begin{tabular}{llllll}
\hline $\mathbf{2 0 1 2}$ & $\mathbf{2 0 1 4}$ & $\mathbf{2 0 1 6}$ & $\mathbf{2 0 1 7}$ & $\mathbf{2 0 1 8}$ & $\mathbf{2 0 1 9}$ \\
\hline 298910 & 420166 & 734874 & 954692 & 1108503 & 1199011 \\
\hline \multicolumn{5}{c}{ Source: Agency of Protected Areas }
\end{tabular}

There is no important benefit in increasing visitation at protected areas unless this is not happening in parallel with increasing benefits of ecotourism businesses and local population (Ceballos-Lascurain, 2008). Georgian National Tourism Administration does not present data of the revenues generated by local population through ecotourism services. Therefore, in the process of the research, it was only possible to obtain information about the revenues generated by protected areas of Georgia.

Table 3. Revenues generated from ecotourism services at protected areas of Georgia (in GEL)

\begin{tabular}{|c|c|c|c|c|c|c|c|c|c|c|c|}
\hline 2008 & 2009 & 2010 & 2011 & 2012 & 2013 & 2014 & 2015 & 2016 & 2017 & 2018 & 2019 \\
\hline 56026 & 84962 & 118 & 420 & 737 & 982 & 1320 & $\begin{array}{ll}1 & 589\end{array}$ & 2313 & $4 \quad 504$ & $8 \quad 436$ & more \\
\hline & & 387 & 189 & 122 & 869 & 793 & 757 & 697 & 472 & 125 & $\begin{array}{l}\text { than } \\
11 \mathrm{mln}\end{array}$ \\
\hline
\end{tabular}

Source: Agency of Protected Areas

Important information about the revenues generated by the local population has been considered based on the report of Dr. Julius Arnegger, which was conducted in March 2018. The report "Economic impacts of tourism in Georgian Protected Areas" is the first study in Georgia that analyzes economic impacts of tourism around five protected areas and shows the benefits of local communities living there. The report also illustrates economic output of local communities as well as the employment effect of ecotourism in these villages for 2018. The result of the study revealed that in 2018, economic output effect of more than $80 \mathrm{mln}$ Gel (approximately USD $30 \mathrm{mln}$ ) was created from ecotourism services (in the surrounding villages of five protected areas only). 
Figure 1. Economic impacts of tourism around 5 protected areas

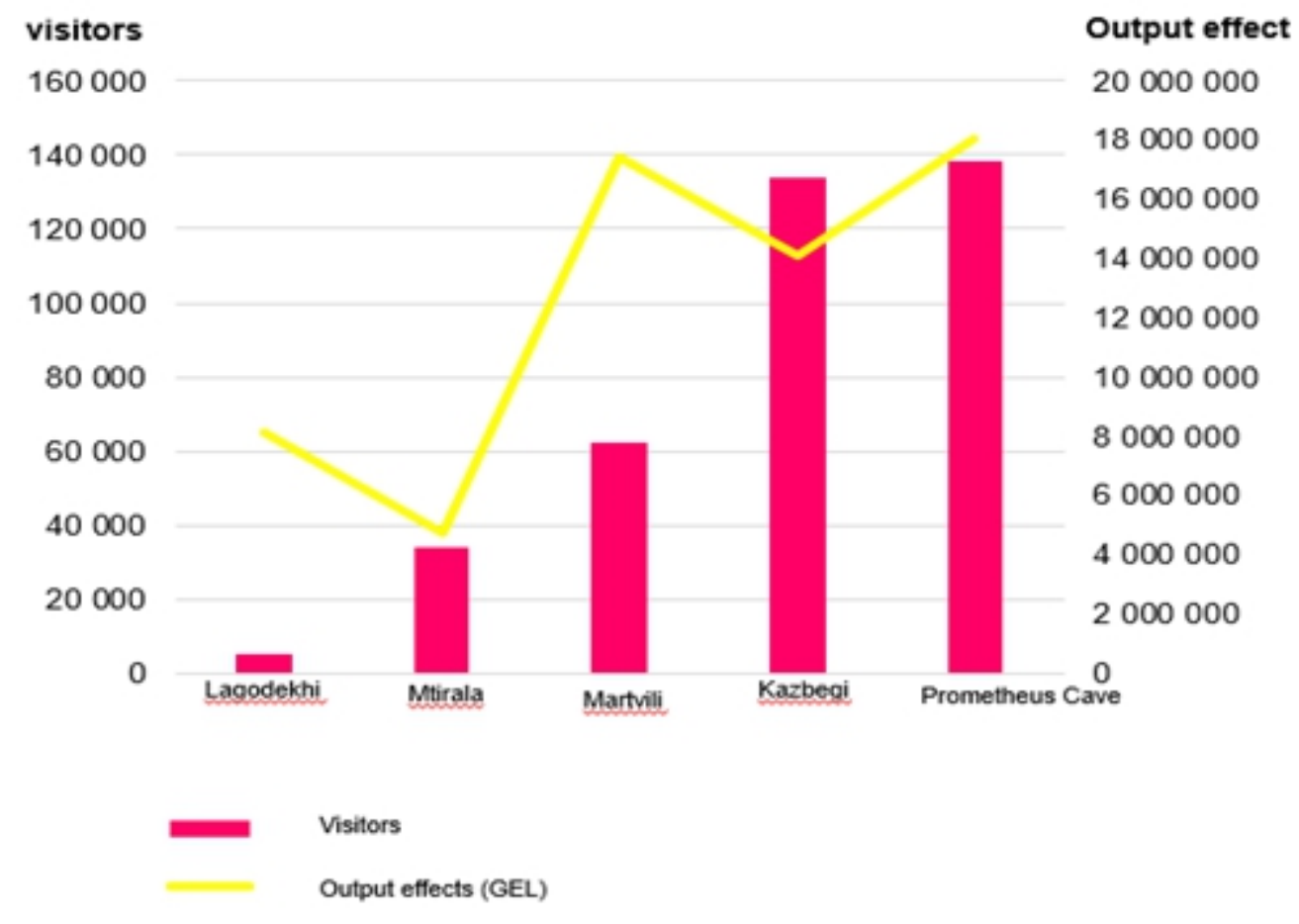

\section{Survey}

This section presents the survey applied to the managers of Protected Areas of Georgia. Respondents from 5 most popular Protected Areas were selected to collect information about the opinion of the local population living adjacent to protected areas. The selected respondents are the ones who have the closest contact with tour operators, agencies, visitor centers, and local guesthouses. This means that they provide service to hundreds of people daily and are aware of the requirements of tourists. The questionnaires were developed in the way that they could elicit information on various topics related to the needs and readiness for ecotourism cluster establishment in Georgia.

The selected protected areas were Lagodekhi Protected Areas (PA), Kazbegi National Park (NP), Martvili Canyon Natural Monument (NM), Borjomi-Kharagauli National Park (NP), and Machakhela National Park (NP). Protected Areas are managed by Territorial Administrations.

Questionnaires were distributed to 54 representatives of the administrations:

- Lagodekhi Protected Areas - 7 representatives

- Kazbegi National Park - 10 representatives

- Martvili Canyon Natural Monument - 8 representatives 
- Borjomi-Kharagauli National Park - 21 representatives

- Machakhela National Park - 8 representatives

Protected areas managers were asked 12 questions. 5 questions were asked to each administration and they had to give one joint answer, while 7 questions required personal answers.

\section{Questions for Administrations}

1) How many tourists visited the administration in 2019?

Figure 2. Number of visitors at protected areas in 2019



It is worthy to note that the selected protected areas were visited by 520,543 tourists in 2019, while the total number of visitors at protected areas was $1,199,011$. Thus, the percentage of the total visitors is $43 \%$. This implies that most of the ecotourism potential of the country is gathered in these areas.

2) What is the growth rate of the number of tourists at the protected area (in comparison with $\mathbf{2 0 1 8}$ )?

Figure 3. Growth rate of the number of visitors at protected areas in 2019

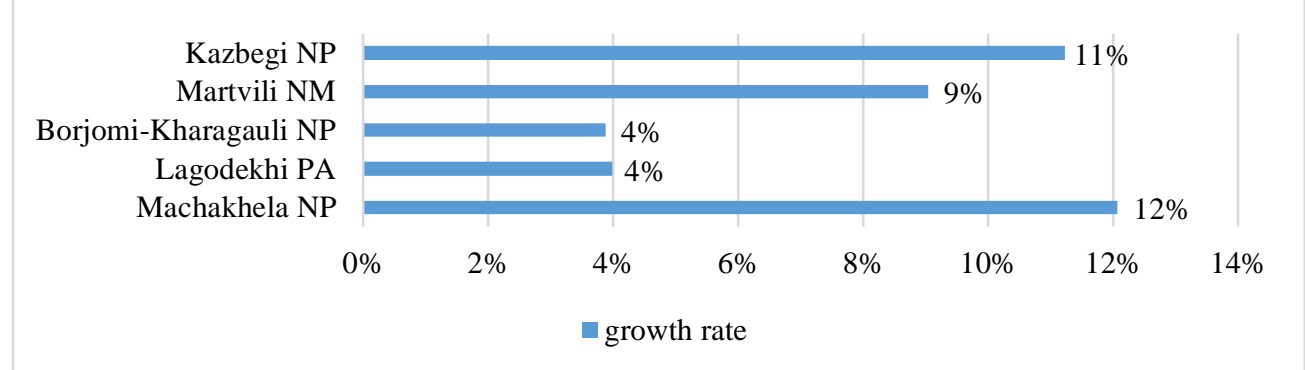


3) What is the percentage of the number of tourists increase in the last three years?

Figure 4. Growth rate of the number of visitors at protected areas in 2016-2019



Figure 3 and Figure 4 shows that each protected area has positive growth rate in terms of visitors. There was about $8 \%$ average growth rate in 2019 , and it increased to about $150 \%$ within 3 years period. The responses indicate that the number of tourists grows annually. This means that the attractiveness of protected areas of Georgia is gradually increasing.

\section{4) Approximately how many ecotourism businesses (guesthouses, cafes, adventurous tour operators, etc.) operate near the protected area?}

Figure 5. Number of businesses operating near protected areas

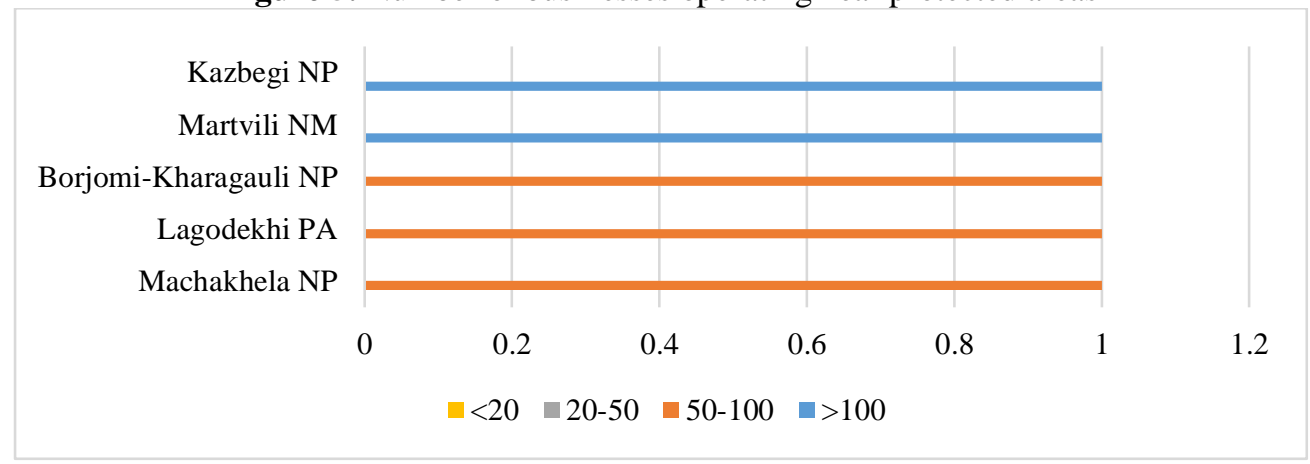

The administrations were also asked about the number of ecotourism businesses near protected areas. Machakhela NP, Lagodekhi PA, and BorjomiKharagauli NP administrations opined that there are 50-100 ecotourism businesses operating. It is logical that the responses show more business units in the case of Kazbegi NP and Martvili NP. This is because they are more developed, they have more visitors and, consequently, more people are involved in ecotourism industry. 
5) What ecotourism services are in demand at protected areas?

Table 4. Demanded ecotourism services at protected areas

\begin{tabular}{llllll}
\hline & $\begin{array}{l}\text { Lagodekhi } \\
\text { PA }\end{array}$ & $\begin{array}{l}\text { Borjomi- } \\
\text { Kharagauli } \\
\text { NP }\end{array}$ & $\begin{array}{l}\text { Machakhela } \\
\text { NP }\end{array}$ & $\begin{array}{l}\text { Martvili } \\
\text { NM }\end{array}$ & Kazbegi NP \\
\hline Hiking & $\mathrm{X}$ & $\mathrm{X}$ & $\mathrm{X}$ & & $\mathrm{X}$ \\
\hline $\begin{array}{l}\text { Horse } \\
\text { Riding }\end{array}$ & $\mathrm{X}$ & $\mathrm{X}$ & & & \\
\hline picnics & & $\mathrm{X}$ & $\mathrm{X}$ & \\
\hline $\begin{array}{l}\text { Overnight in } \\
\text { eco-lodges }\end{array}$ & $\mathrm{X}$ & $\mathrm{X}$ & & $\mathrm{X}$ & \\
\hline camping & $\mathrm{X}$ & $\mathrm{X}$ & $\mathrm{X}$ & \\
\hline $\begin{array}{l}\text { Visiting } \\
\text { canyon }\end{array}$ & & & & $\mathrm{X}$ & \\
\hline $\begin{array}{l}\text { Visiting } \\
\text { waterfalls }\end{array}$ & & & $\mathrm{X}$ & \\
\hline Boating & & & & $\mathrm{X}$ & \\
\hline Zip-line & & &
\end{tabular}

The table above illustrates the diversity of services that are provided at protected areas. This reveals that each protected area has potential and people have the opportunity to start their own ecotourism business, serve tourists, and earn revenues.

\section{Individual Questions}

6) Does the protected area have the potential to host more visitors?

Figure 6. Respondents' opinion on ecotourism businesses cooperation

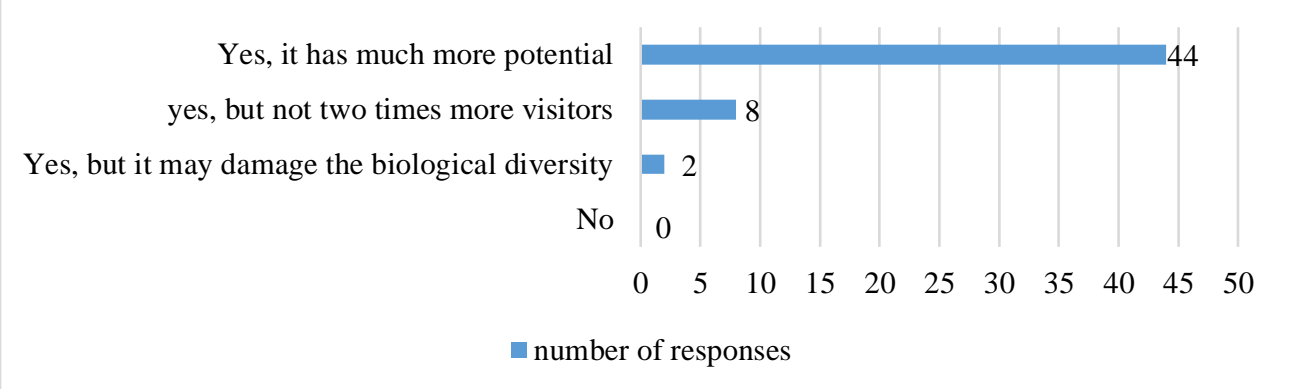


7) Do ecotourism businesses (guesthouses, cafes, adventurous tour operators, etc.) cooperate with each other?

Figure 7. Respondents' opinion on ecotourism businesses cooperation

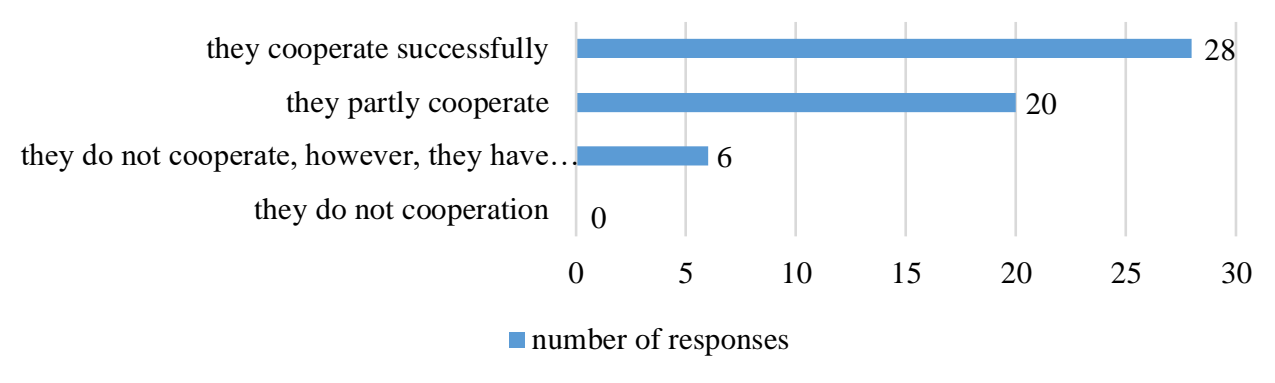

When asked this question "Do you think ecotourism businesses cooperate with each other", $52 \%$ of Protected Areas managers responded that they do. Additional $37 \%$ of respondents evaluated the cooperation as partial. The rest $11 \%$ fixed their positions that they do not cooperate, however, they have an intention, just that they do not know how to do that.

\section{8) What do you think is the maximum revenue generated from all ecotourism businesses around the protected areas throughout the year?}

Figure 8. Respondents' opinion on the amount of revenue ecotourism businesses generate throughout the year

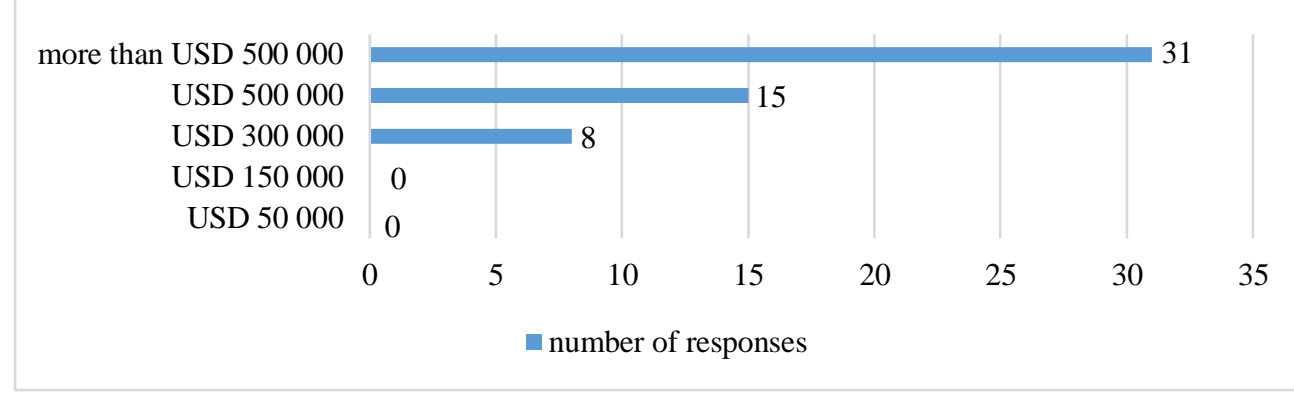

Figure 8 illustrates the approximate revenues of local communities generated through ecotourism services. Majority of respondents indicated the maximum amount in the proposed answers. 57.4\% are of the opinion that revenues of local people exceed USD 500000. 
9) What percentage of nearby living population is involved in ecotourism businesses?

Figure 9. Respondents' opinion on the size of population involved in ecotourism businesses

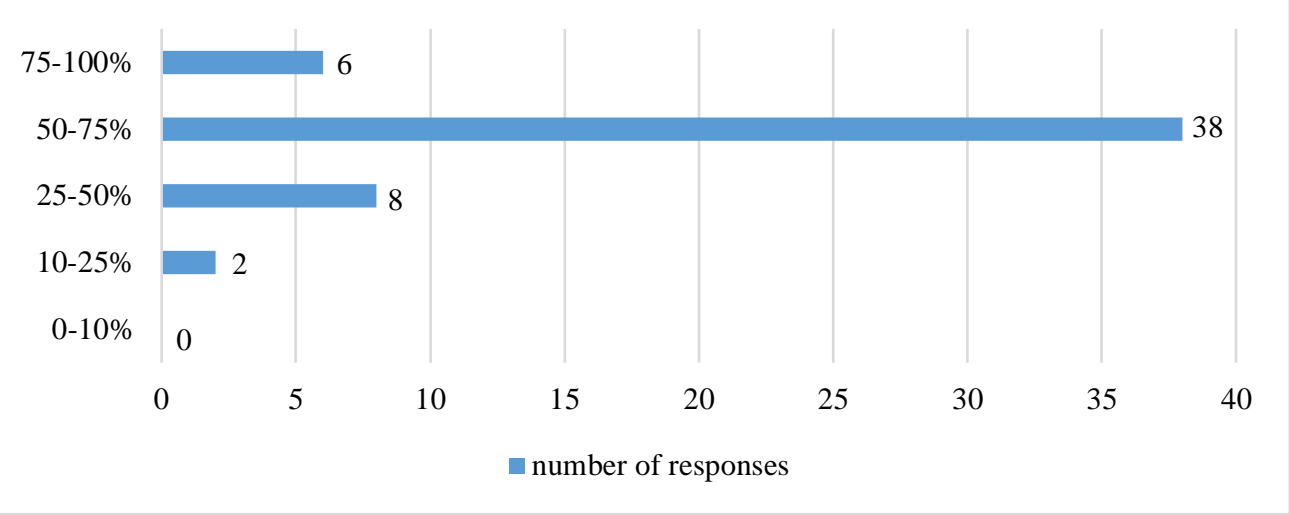

Figure 9 shows the opinion of the respondents about the approximate percentage of local communities involved in ecotourism activities. Majority (70\%) of the respondents stated that $50-75 \%$ of the population is engaged in businesses. This also points to the importance of the industry on the local economy.

\section{0) Is it reasonable to establish an ecotourism cluster in Georgia?}

Figure 10. Respondents' opinion on establishing ecotourism cluster

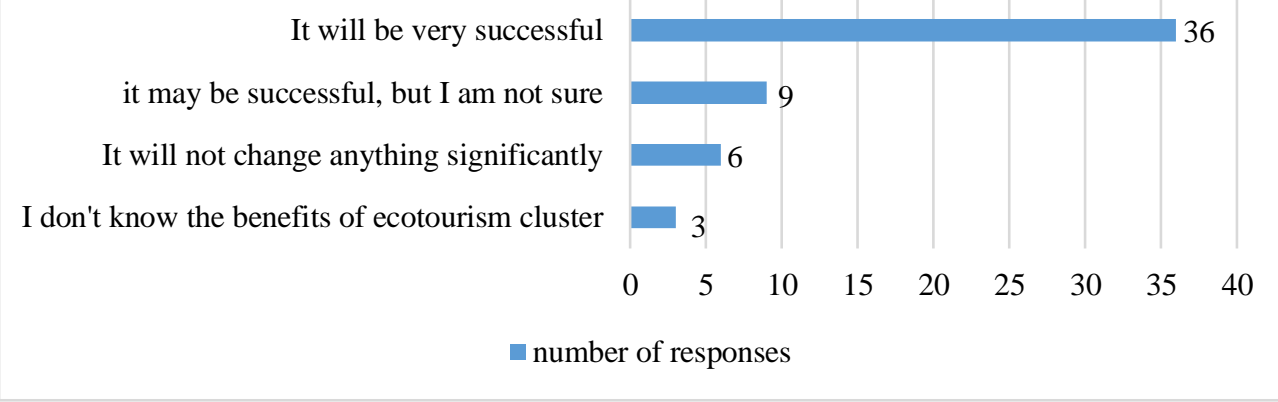

When asked this question "Do you think it would be reasonable to establish an ecotourism cluster", $67 \%$ of the respondents answered that it would be successful. They realized that in ecotourism, cluster businesses will cooperate. Also, with mutual efforts, more economic benefits will be created. 


\section{1) Do you think that companies providing ecotourism services are willing to join ecotourism cluster?}

Figure 11. Respondents' opinion on the willingness of ecotourism businesses to join cluster

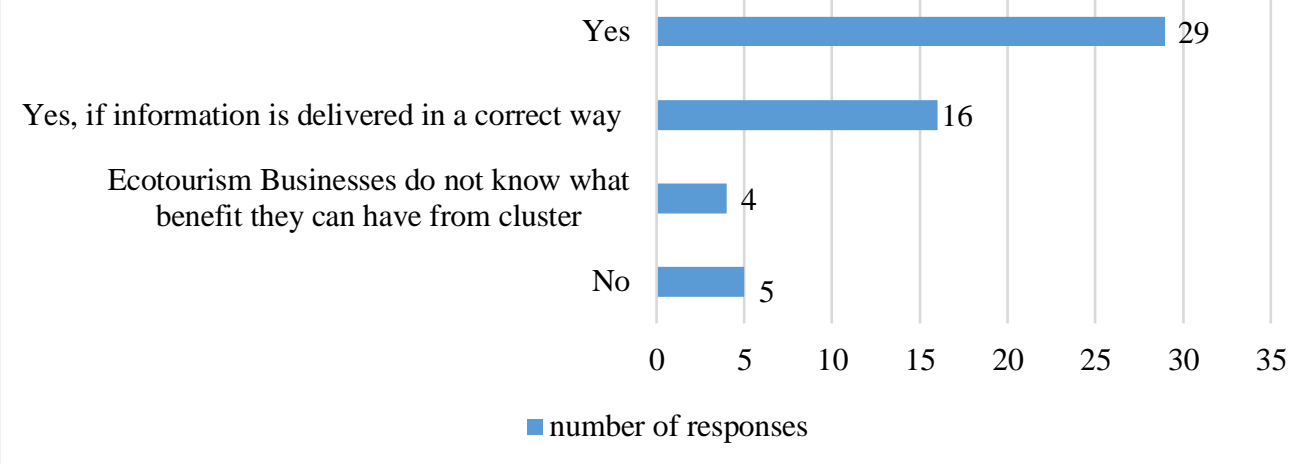

When asked whether companies providing ecotourism services are willing to join ecotourism cluster, $54 \%$ responded positively. Conversely, $9 \%$ of participants gave a negative response.

\section{2) What will be the effect of ecotourism cluster on the competitiveness of the country?}

Figure 12. Respondents' opinion about the effect of cluster on competitiveness of Georgia

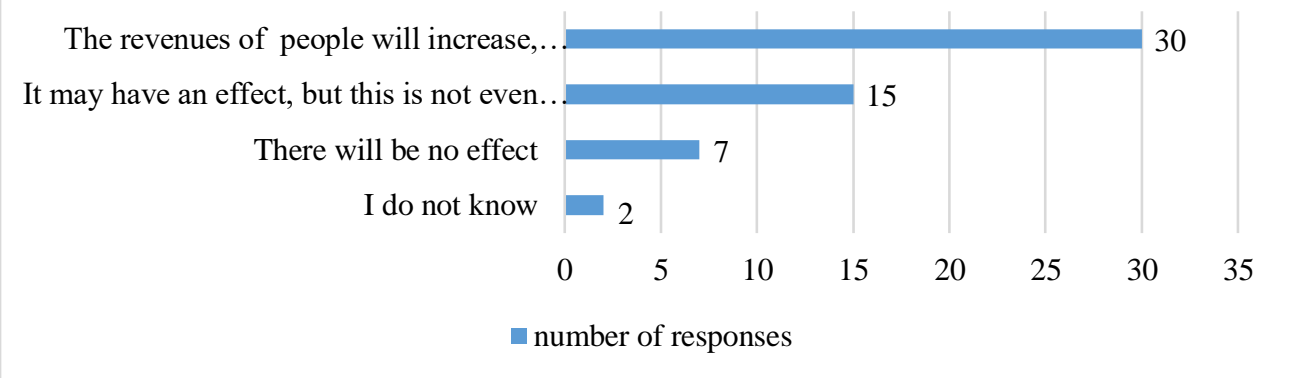

The last question was related to the competitiveness of Georgia. Respondents were asked whether ecotourism cluster could affect the competitiveness of the country. 30 respondents out of 54 are of the opinion that establishing ecotourism cluster can affect the socio-economic situation in the country. They indicated their positions which revealed that through ecotourism cluster the revenues of people would increase, economic prosperity would be created and, accordingly, the country's competitiveness would be raised. 


\section{Results}

The representatives of the protected areas were asked questions on important aspects, and the following conclusions were drawn:

- Selected protected areas are important enough to consider them relevant for the survey (Q1-Q6, Q8, Q9)

- Ecotourism businesses partly cooperate with each other and have the intention to join ecotourism cluster (Q7, Q10, Q11)

- Ecotourism cluster will improve the socio-economic conditions of the local population (Q6, Q10; Q11)

- Ecotourism cluster will have an effect on the competitiveness of Georgia (Q12)

There are 87 protected areas in Georgia (Agency of Protected Areas, n.d.), and 14 of them are strict nature reserves. There are only about 20 protected areas out of the remaining 73 where tourists usually visit (Agency of Protected Areas, n.d.). The survey has been carried out in 5 of them, which covers $25 \%$ of the areas where ecotourists prefer to spend time.

The analysis of the data has revealed that in 2019, Protected Areas of Georgia generated more than 11 million GEL (about USD $5 \mathrm{mln}$ ) from tourism related services. Most ecotourism services that visitors enjoy are camping, picnic sites, overnight in tourist shelter and bungalows, overnight in tents, mountain biking, panton, cater, kayak, boat services, horse riding, zip lines, rope parks, fly fishing, diving, etc. The income generated from the services is still reinvested in the development of protected areas and creation of more comfortable environment for visitors' enhanced satisfaction.

After analyzing the data of the number of visitors and the revenues, the potential of ecotourism can be clearly seen. The table below shows that in 2019 , the number of visitors at protected areas increased by $8.2 \%$. On the other hand, the revenues generated through different services increased by more than $30 \%$.

Table 5. Comparison of the number of visitors and revenues of protected areas in 2018 and 2019

\begin{tabular}{lllcc}
\hline & $\mathbf{2 0 1 8}$ & $\mathbf{2 0 1 9}$ & increase & Increase in \% \\
\hline Number of visitors & 1108503 & 1199011 & 90508 & $8.2 \%$ \\
\hline Revenues (GEL) & 8436125 & More than 11 mln & More than 2563875 & More than 30.4\% \\
\hline
\end{tabular}

The table above is an excellent evidence of the role of ecotourism in the economy. The study of Dr. Julius Arnegger (2018) on the "Economic Impacts of Tourism in Georgian Protected Areas" also points to significant paybacks from ecotourism. Every ecotourist brings huge contribution to the country's economy. Georgia has unique biodiversity and huge potential to host millions of tourists. Against the backdrop of the situation, ecotourism offers 
wonderful opportunities for development. Table 5 points out that as soon as the number of visitors increased by $8.2 \%$, revenues for locals increased by $30.4 \%$. The following result definitely underlines the huge economic benefit that could be achieved once it is developed in a sustainable way.

\section{Conclusion}

In the scientific assessments, Michael Porter proves that clusters foster the process of creating economic prosperity. Within the cluster, cooperation is more fruitful and this brings more benefit to the participants. They find it easy to access information, start a business, find partners, and offer services to the target market.

The results of the study showed the need of ecotourism cluster development in Georgia. Country has a huge potential of hosting 2-3 times more international visitors at the same time, and this potential needs to be entirely utilized to create more economic benefits. The results of the survey also identified that ecotourism businesses partly cooperate with each other. Furthermore, in order to maximize returns from ecotourism industry, businesses should cooperate. Frequent and easy ways of exchanging information, interchanging resources, and sharing knowledge and practice can subsequently form strong networks and encourage the achievement of the $1+1=3$ effect. It was a positive remark that businesses which engaged in ecotourism industry expressed the willingness to join the cluster and obviously consider it reasonable to initiate its establishment.

Undoubtedly, the benefit of cluster and the added value it brings to the country's economy is significant. Effective operation of ecotourism cluster contributes to increasing productivity in the country. Productivity is the main factor driving economic growth. In the long run, it has the ability to improve the standard of living and cover all aspects of prosperity. This includes not only economic but also environmental and social considerations. Prosperity within the country is a vital tool to grow more sustainable and inclusive industries. This is closely linked to fostering the country's competitiveness.

Another interesting fact that was revealed after the study is that the respondents noted the influence of ecotourism development in enhancing the country's image at the international level. As a result of the study, it can be stated that ecotourism development can have a significant impact on the competitiveness of Georgia and also affect the country's positions in Global Competitiveness Report.

Furthermore, the country's competitiveness at the regional level is quite high. On the one hand, Armenia and Azerbaijan are both part of South Caucasus region and the positions of Georgia in terms of ecotourism is incomparable. Also, the number of international visitors in Armenia has never exceeded 2 million. On the other hand, Azerbaijan is positioning more as a 
MICE tourism ${ }^{3}$ destination rather than as a recreational tourism. Georgia, being located at the crossroad of Asia and Europe, is surrounded with high mountains and situated in the middle of two seas. This in addition to its unique culture and ancient history creates an outstanding destination for adventurous tourism.

\section{References:}

1. Agency of Protected Areas (n.d.). Statistics. Retrieved April 29, 2020, from https://apa.gov.ge/en/saagento/saagentos-misia

2. Arnegger, J. (2018). Economic impacts of tourism in Georgian Protected Areas. "Ecoregional Nature Protection Programme in the southern Caucasus Region - Support Programme for PAs in the Caucasus - Georgia".

3. Baratashvili, E., Kurashvili, G., \& Makharashvili, G. (2018). Competitive management in establishing a cluster of Georgian winemaking. The challenges of globalization in economics and business. p. 51-53.

4. Bliadze, M. (2015). What is Ecotourism. [Weblog]. Retrieved from http://mastsavlebeli.ge/?p=1084

5. Ceballos-Lascuráin, H. (2008). The ECOCLUB Interview with the 'Architect of Ecotourism'. Retrieved October 15, 2020, from https://ecoclub.com/news/085/interview.html

6. Chigogidze, Kh. (2016). Ecotourism - unique perspective of Georgia. Gza. Retrieved from http://gza.kvirispalitra.ge/qveyana/4066ekoturizmi-saqarthvelos-unikaluri-perspeqtiva.html

7. Colchis RainForests and Wetlands nominated as UNESCO World Heritage List (2019). [Weblog]. Retrieved from http://www.ghn.ge/news/220379

8. Darsavelidze, D. (2014). Mechanisms of Local Economic Development (on the example of tourist clusters of Thessaloniki, Napa Valley and Tbilisi). (Doctoral dissertation). Retrieved from http://www.press.tsu.ge/data/image_db_innova/Disertaciebi_economi cs/davit_darsvelidze.pdf

9. Diasamidze, M. (2015). Formation of clusters in the tourism industry and increase of competitiveness of the regional tourism market. (Doctoral dissertation). Retrieved from https://www.bsu.edu.ge/text_files/ge_file_5470_1.pdf

10. Drumm, A. \& Moore, A. (2005). Ecotourism Development - A Manual for Conservation Planners and Managers. Volume I - An Introduction to Ecotourism Planning

${ }^{3} \mathrm{MICE}$ tourism - Meetings, incentives, conferences, exhibitions 
11. Gagnidze, I. (2012). Country Competitiveness and Clusters: History and Nowadays. Publishing House "Universal". p. 73-118.

12. Gavasheli, M. (2018). Tourism and its impact on the development of the regional economy. Retrieved from http://dl.sangu.edu.ge/pdf/dissertacia/mgavasheli.pdf

13. Georgia's Colchic Rainforests and Wetlands nominated as UNESCO World Natural Heritage Site (2019). [Weblog]. Retrieved from https://www.europarc.org/news/2019/12/georgias-colchic-rainforestsand-wetlands-nominated-as-unesco-world-natural-heritage-site/

14. Georgian National Tourism Administration (2018). Georgian Tourism in Figures: Structure \& Industry Data. Retrieved from https://gnta.ge/wp-content/uploads/2019/06/2018-ENG.pdf

15. Georgian National Tourism Administration (n.d.). Research. Retrieved November 7, 2020, from https://gnta.ge/statistics/

16. Giacomin, V. (2017). A Historical Approach to Clustering in Emerging Economies. Working Paper 18-018. Retrieved from https://www.hbs.edu/faculty/Publication\%20Files/18-018_0dfb3cfbf397-4aeb-9e40-532e174981cf.pdf

17. Gogelia, M. (2013). Formation of ecological tourism development strategies. (Doctoral dissertation). Retrieved from https://www.bsu.edu.ge/text_files/ge_file_3292_1.pdf

18. Government of Georgia (1996). Law on the System of Protected Areas (003, 07/03/1996). Tbilisi: Legislative Herald of Georgia N136.

19. Hackett, P. (2019). The power of business clusters. [Weblog]. Retrieved from https://www.euronews.com/2019/05/17/the-power-ofbusiness-clusters

20. Hanna, J. (2017). How Economic Clusters Drive Globalization. Harvard Business School. Retrieved from https://hbswk.hbs.edu/item/how-economic-clusters-driveglobalization

21. Ketels, C. \& Protsiv, S. (2017). European Cluster Panorama 2016. Retrieved from http://ec.europa.eu/DocsRoom/documents/20381

22. Ministry of Environment and Natural Resources Protection of Georgia (n.d.). Georgia's Fifth National Report to the Convention on Biological Diversity. Retrieved from https://www.cbd.int/doc/world/ge/ge-nr-05en.pdf

23. Ministry of Environmental Protection and Agriculture of Georgia (n.d.). Colchic Rainforests and Wetlands. Retrieved from https://drive.google.com/file/d/1G4VrcKHv4AF9uIuiGphbsRI3JDzs $\mathrm{Sr} 1 \mathrm{O} / \mathrm{view}$

24. National Statistics Office of Georgia (n.d.). Statistical information. Retrieved February 02, 2020, from https://www.geostat.ge/ 
25. Porter, M. (1990). The Competitive Advantage of Nations. New York: The Free Press

26. Porter, M. (2008). On Competition. Harvard Business School Publishing

27. Sekhniashvili, M. (2016). Development of Ecotourism in Georgia. [Weblog]. Retrieved from http://mastsavlebeli.ge/?p=9919

28. Sepashvili, E. (2014). The role of clusters in increasing the competitiveness of the country. Retrieved from http://eprints.tsu.ge/837/1/The\%20Role\%20of\%20Clusters $\% 20 \mathrm{in} \% 2$ 0Rising\%20the $\% 20$ Global\%20Competitiveness $\% 20$ of $\% 20$ the $\% 20$ Co untry.pdf 